\title{
Fecundity of Morocco Dentex Dentex maroccanus Valenciennes, 1830 Distributed in Izmir Bay (Central Aegean Sea of Turkey)
}

\author{
Burcu Taylan*, Bahar Bayhan, Oğulcan Heral
}

Department of Hydrobiology, Faculty of Fisheries, Ege University, 35100 Izmir, Turkey

\section{A R T I C LE IN F O}

\section{Research Article}

Received 21 February 2018

Accepted 27 March 2018

Keywords:

Dentex maroccanus

Morocco dentex

Fecundity

Izmir Bay

Aegean Sea

*Corresponding Author:

E-mail: burcu.taylan@ege.edu.tr \begin{abstract}
A B S T R A C T
In this study, the reproductive properties of the Dentex maroccanus species distributed in the Aegean Sea were determined. A total of 439 fish were collected during the period from December 2012 to March 2014 from the commercial fishers who seasonally hunt in the Foça-Mordoğan region (İzmir, Turkey) were examined. After the measurement of the total lengths and body and gonad weights of the fish samples in the laboratory, their sexes were identified, which revealed that 140 of the samples were male, 206 of the samples were female and 93 of the sample were undeterminated. The female:male ratio was 1.5:1. The 5-point maturity phase discrimination method developed by Holden and Raitt for maturity stages in 1974 was macroscopically examined for female and male fish specimens. A total of 16 ovaries, which were determined to be at the $3^{\text {rd }}$ and $4^{\text {th }}$ stages of maturity according to the method, were used to determine fecundity. The gonadosomatic index values that were calculated based on the seasons revealed that the reproductive period of the species was summer (2.87) and autumn (2.10). The first maturation length for the species was $13.4 \mathrm{~cm}$. Estimates of total fecundity varied between 74252 and 201187 eggs (mean: 123263 \pm 44586 ). There was an exponential relationship between fecundity and total length as $\mathrm{F}=10.643 \mathrm{~L}^{3.111}$. The diameter of the mature eggs ranged from $0.49 \mathrm{~mm}$ to $0.67 \mathrm{~mm}$ (mean: $0.59 \pm 0.06 \mathrm{~mm}$ ).
\end{abstract}

DOI: https://doi.org/10.24925/turjaf.v6i5.624-627.1865

\section{Introduction}

The Sparidae family is represented by 10 genera and 21 species in the Turkish seas (Bilecenoğlu et al., 2014) and the total hunting amount is 5000 tons, which adds up to $2.9 \%$ of the total fish production in Turkey (TUIK, 2016). The Pagellus, Pagrus and Dentex genera of the Sparidae family is made up of breams and Dentex maroccanus, known as Morocco Dentex, is a species from the Dentex genus (Froese and Pauly, 2015). The species mostly distributes in the northern regions from Bay of Biscay in the Atlantic Ocean to Gulf of Guinea and lives at depths of $50 \mathrm{~m}$ to $200 \mathrm{~m}$ in the Atlantic Ocean and of about $250 \mathrm{~m}$ in the Mediterranean Sea. The species is distributed especially on rocky bottoms in coastal waters and its reproductive season in the Atlantic Ocean is spring and summer, whereas it is spring in the Mediterranean Sea (Whitehead et al., 1986).

There are limited studies on the reproductive properties of the D. maroccanus species. In their elaborate study on the biology of the species in the Safi region of Morocco, Lamrini and Bouymajjane (2002) examined the ratio of the sexes and first maturation length and carried out the determination of the reproductive season using the gonadosomatic indexes (GSI) and reproductive properties such as fecundity. Mohdeb and Kara (2014) made mention of some of the reproductive properties of the species distributed in the Algerian coasts, which include the sex ratio, determination of the reproductive season, and first maturation length. In Turkey, in their study on the biology of the species living in Saroz Bay (the North Aegean Sea), Gül et al. (2014) determined the reproductive properties such as sex ratio, determination of the reproductive season, first maturation length, fecundity, and relationship between fecundity and length.

The reproduction studies in fishery biology focus on females because of by far the greater effect of egg count on offspring production (Murua and Saborido-Rey, 2003). Thus, the information about the fecundity, i.e., egg yield, length at reproductive maturity, duration of the reproductive season, and sex ratios of the females is of great importance in the studies on the management model for the regulation and control of the fishery industry and population dynamics and help further our knowledge of the status of the stocks (Murua et al., 2003; Huppell and Sullivan, 2000). The management model for the regulation and control of the fishery industry is important in population dynamics. 
In this study, reproduction parameters such as the sex ratio, reproductive season, first maturation length, egg yield and its relationship with total length, and diameters of mature eggs of the species distributed in the Central Aegean Sea were determined. In addition to the only study on the reproductive properties of the species in the Turkish seas (Gül et al., 2014), this study reveals the egg diameter and other related values of the species. In ichthyoplankton science, egg diameter is one of the most important criteria used in the identification of the species. Especially the eggs of the species from the Sparidae family are quite similar and difficult to distinguish. Although, after fertilization, the eggs swell as a result of the water intake due to osmotic pressure, the mature eggs in the ovarium give, albeit little, information about the egg diameter of the species. However, there were no findings on the egg diameter of the species thus far. Today, in stock assessment studies, research about eggs and larvae are prevalently used (Somarakis et al., 2004; Somarakis et al., 2006; Stratoudakis et al., 2006; Murua et al., 2010; Taylan and Hossucu, 2016). Therefore, this study is believed to contribute to the stock assessment and fishery management of the species.

\section{Material and Method}

In the study, a total of 439 fish were collected from the commercial fishers hunting seasonally in FoçaMordoğan, İzmir, Turkey, during the period from December 2012 to March 2014. In the laboratory, total length measurements of the fish samples were performed using a $0.1 \mathrm{~cm}$-interval fish measuring board; following the body and gonad weight measurements using a $0.01 \mathrm{~g}$ sensitivity Scaltec electronic scales, sex determination was macroscopically carried out. To determine whether there were statistically significant differences between female and male fish, the chi-square $\left(\chi^{2}\right)$ test was performed. The gonad development of the female fish was determined following the 5-point maturity stage distinction method proposed by Holden ad Raitt (1974) (Table 1).

To determine fecundity, 16 ovaries at the $3^{\text {rd }}$ and $4^{\text {th }}$ stages of maturity from the summer season were fixed in a $4 \%$ formalin solution. Subsamples were collected from the ovaries by taking $2-5 \%$ of the ovaries by weight and the oocytes were counted using the gravimetric method.
Total fecundity was calculated by referring to the total oocyte count in the ovarium and using the $F=(n \times G) / g$ formula (Valladolid and Przybylski, 2008). In the gonadosomatic index calculation to determine the reproductive season, the $\mathrm{GSI}=(\mathrm{BW}-\mathrm{GW}) / \mathrm{GW} \times 100$ formula (King, 1995) was used in which BW represents the body weight and GW represents the gonad weight. Length at first maturity $(\mathrm{Lm})$ was calculated according to the method of King (1996), size at maturity was defined as the size at which $50 \%$ of individuals were mature. An L50 computer program, performed with the LogLog function, was used to determine the length at $50 \%$ maturity (İlkyaz et al., 1998).

\section{Results}

Of a total of 439 fish samples collected during the study, 140 were male, 206 were female, and the sex of 93 fish samples were undetermined. The female: male ratio was 1.5: 1. According to the chi-square $\left(\chi^{2}\right)$ test, $\left(\chi^{2}=0.83<\chi^{2}{ }_{\text {t0.05 }}=3.85, \mathrm{P}<0.05\right)$ there were no statistically significant differences between female and male fish samples.

The gonadosomatic index values according to the seasons revealed that the reproductive period of the species was summer and autumn (Fig. 1). The length at first maturation of the species was $13.4 \mathrm{~cm}$.

The length of the female fish that were used to determine fecundity was $16.6-22.3 \mathrm{~cm}(19.5 \pm 1.7)$ and fecundity was 74252-201187 eggs (123263 \pm 44586$)$. There was an exponential relationship between fecundity and total length as $\mathrm{F}=10.643 \mathrm{~L}^{3.111}$ and the results revealed that the fecundity increased as the female fish grew (Fig. 2 ). The diameter range of the mature eggs was $0.49-0.67$ $\mathrm{mm}(0.59 \pm 0.06 \mathrm{~mm})$.

\section{Discussion}

In the study carried out in İmir Bay, of the 439 fish samples, $31.89 \%$ were male, $46.93 \%$ were female and $21.18 \%$ were undetermined. The sex ratios reported by some studies from around the world and Turkey were $69 \%$ female, $30 \%$ male and $1 \%$ undetermined (Lamrini and Bouymajjane, 2002); $50 \%$ female, $47 \%$ male and $3 \%$ undetermined (Mohdeb and Kara, 2014); 82\% female and $18 \%$ male (Gül et al., 2014).

Table 1 A five-point maturity scale for partial spawners (Holden and Raitt, 1974)

\begin{tabular}{|c|c|c|}
\hline Stage & State & Description \\
\hline I & Immature & $\begin{array}{l}\text { Ovary and testis about } 1 / 3 \text { rd length of body cavity. Ovaries pinkish, translucent; } \\
\text { testis whitish. Ova not visible to naked eye. }\end{array}$ \\
\hline II & $\begin{array}{l}\text { Maturing virgin and } \\
\text { recovering spent }\end{array}$ & $\begin{array}{l}\text { Ovary and testis about } 1 / 2 \text { length of body cavity. Ovary pinkish, translucent; testis } \\
\text { whitish, more or less symmetrical. Ova not visible to naked eye. }\end{array}$ \\
\hline III & Ripening & $\begin{array}{l}\text { Ovary and testis is about } 2 / 3 \text { rds length of body cavity. Ovary pinkish-yellow } \\
\text { colour with granular appearance, testis whitish to creamy. No trans- parent or } \\
\text { translucent ova visible. }\end{array}$ \\
\hline IV & Ripe & $\begin{array}{l}\text { Ovary and testis from } 2 / 3 \text { rds to full length of body cavity. Ovary orange-pink in } \\
\text { colour with conspicuous superficial blood vessels. Large transparent, ripe ova } \\
\text { visible. Testis whitish- creamy, soft. }\end{array}$ \\
\hline V & Spent & $\begin{array}{l}\text { Ovary and testis shrunken to about } 1 / 2 \text { length of body cavity. Walls loose. Ovary } \\
\text { may contain remnants of disintegrating opaque and ripe ova, darkened or } \\
\text { translucent. Testis bloodshot and flabby. }\end{array}$ \\
\hline
\end{tabular}




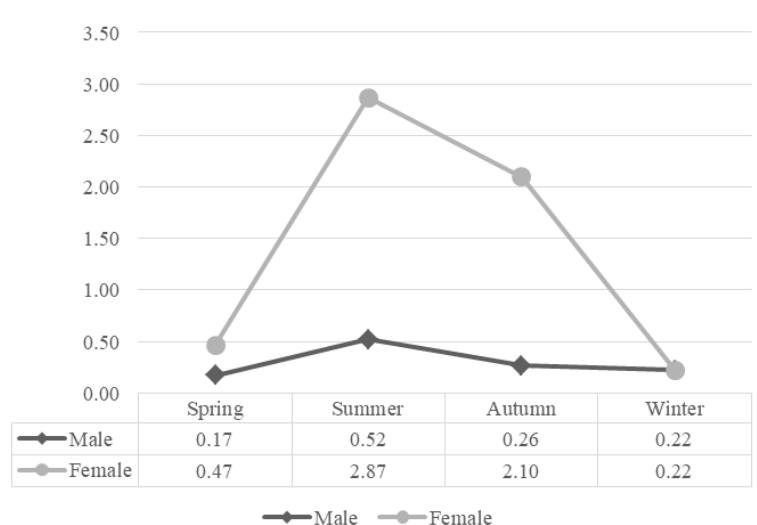

Figure 1 Seasonal variation of GSI in females and males

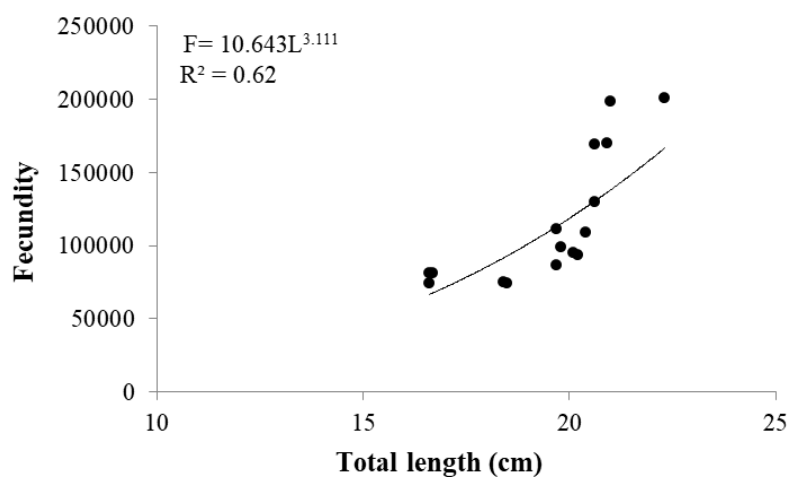

Figure 2 Fecundity-total length relationship of Dentex maroccanus

The previous studies revealed that the female fish were dominant, which agrees with the findings of this study. In this study, the female: male ratio was $1.5: 1$, while it was 1:0.9 in the study published by Mohdeb and Kara (2014) and 4.8:1 in the study published by Gül et al. (2014). The results reveal that female fish are dominant.

The findings both in this study and in other studies show that the reproductive season of the species is spring and autumn (Bauchot and Hureau, 1990; Lamrini and Bouymajjane, 2002; Mohdeb and Kara, 2014; Gül et al., 2014).

Gül et al. (2014) determined the first maturation length of females as $13.0 \mathrm{~cm}$, which was found to be 13.4 $\mathrm{cm}$ in this study. The number of the studies on the egg yield of the species is quite insufficient. Gül et al. (2014) found that the fecundity of the species varied between 65.000 eggs and 362.000 eggs and determined an exponential relationship between fecundity and length $\left(\mathrm{F}=0.981 . \mathrm{L}^{3.991}\right)$ in Saroz Bay (Central Aegean Sea). The egg yield determined in this study was between 74.252 eggs and 201.187 eggs. There was an exponential relationship between fecundity and length $\left(\mathrm{F}=10.643 . \mathrm{L}^{3.111}\right)$. The difference between the fecundity values found in this study and the previous study was attributed to the length of the samples. Gül et al. (2014) used samples with a maximum length of $25.2 \mathrm{~cm}$, while the maximum length of the sample used in this study to determine fecundity was $22.3 \mathrm{~cm}$. In their study, Lamrini and Bouymajjane (2002) determined a mean egg yield of 100510 eggs. In this study, the mean egg yield was determined to be 123263 eggs, which agrees with the results of the previous study.
The reproductive potential of a population is affected by many factors including spawning stock biomass (Bagenal, 1973; Myers and Barrowman, 1996), age and density of mature individuals (Alheit et al., 1983; Cardinale and Arrhenius, 2000), the ratio of the first and repetitive spawners (Evans et al., 1996; Trippel, 1998), the availability of food in the environment (Hislop et al., 1978; Hunter and Leong, 1981; Brooks et al., 1997), and sexual maturity length and age (Roof, 1981; Morgan and Hoening, 1997). Fecundity studies are of great importance in total population assessments, productivity and population dynamics studies, and the determination of the specific properties of the populations, subpopulations, and/or fish stocks (De Martini and Sikkel, 2006). Thus, fishery research increasingly includes these studies (Murua et al., 2003; Murua and Saborido-Rey, 2003; Trippel, 2003; Hutchings and Reynolds, 2004; Jacobsen et al., 2009).

\section{References}

Alheit J, Alegre B, Alarcón H, Macewicz BJ. 1983. Batch fecundity and spawning frequency of various anchovy (Genus: Engraulis) populations from upwelling areas and their use for spawning biomass estimates. FAO Fish. Rep., 291:977-985.

Bagenal TB. 1973. Fish fecundity and its relations with stock and recruitment. ICES Rapp. Proc. -Verb., 164: 186-198.

Bauchot ML, Hureau JC. 1990. Sparidae. In J.C.Quero, J.C Hureau, C. Karrer, A. Post \& L. Saldanha (eds). Checklist of the fishes of the eastern tropical Atlantic (CLOFETA). JNICT, Lisbon ; SEI, Paris and UNESCO, Paris, Vol. 2, 790-812 pp.

FISHBASE, Family details for Sparidae (05/2015).

Bilecenoğlu M, Kaya M, Cihangir B, Çiçek E. 2014. An updated checklist of the marine fishes of Turkey. Turkish $\mathrm{J}$ of Zoology, 38: 901-929 pp.

Brooks S, Tyler CR, Sumpter JP. 1997. Egg quality in fish: what makes a good egg? Fish. Biol. Fish., 7: 387-416.

Cardinale M, Arrhenius F. 2000. The influence of stock structure and environmental conditions on the recruitment process of Baltic cod estimates using a generalized additive model. J. Fish. Aquat. Sci., 57: 2402-2409.

DeMartini E, Sikkel P. 2006. Reproduction. The Ecology of Marine Fishes California and Adjacent Waters, pp.482-523.

Evans RP, Parrish CC, Brown JA, Davis PJ. 1996. Biochemical composition of eggs from repeat and first-time spawning captive Atlantic halibut (Hippoglossus hippoglossus). Aquaculture, 139: 139-149.

Froese R, Pauly D. Editors. 2015. FishBase. World Wide Web electronic publication. www.fishbase.org, version (09/2015).

Gül G, İşmen A, Arslan M. 2014. Age, growth and reproduction of Dentex maroccanus (Actinopterygii: Perciformes: Sparidae) in the Saros bay, Acta Ichthyologica et Piscatoria, 44(4): 295-300pp.

Hislop JRG, Robb AP, Gauld JA. 1978. Observations on effets of feding level on growth and reproduction in haddock, Melanogrammus aegleginus (L.), in capticity. J. Fish. Biol., 13: 85-98.

Holden MJ, Raitt DFS. 1974. Manual of fisheries science. Part 2- Methods of resource investigation and their application. Rome: Food and Agriculture Organization of the United Nations.

Hutchings JA, Reynolds JD. 2004. Marine Fish Population Collapses: Consequences for Recovery and Extinction Risk. BioScience, 54(4): 297-309. 
Hunter JR, Leong JH. 1981. The spawning energetics of female northern anchovy, Engraulis mordax. Fish. Bull. U.S., 79: 215-230.

Huppell SA, Sullivan CV. 2000. Reproduction of blue fin tuna: Assessing maturity using sex specific compounds present in muscle. Proceeding of a workshop on the biology of blue fin tuna in the mid Atlantic 5-7 May 2000 Bermuda.

İlkyaz A, Metin C, Kınacıgil HT. 1998. Örtü torba yöntemi ile örneklenen sürütme ağlarında seçicilik parametrelerinin hesaplanması üzerine bir bilgisayar programı (L50 sürüm 1.0.0). EgeJFAS, 15: 305-314 (in Turkish).

Jacobsen T, Fogarty MJ, Megrey BA, Moksness E. 2009. Fish Reproduction Biology: Implications for Assessment and Management. Blackwell Publishing, 440 p.

TUIK 2016. Türkiye İstatistik Kurumu 2013 Y1lı Su Ürünleri İstatistikleri, Ankara, $61 \mathrm{~s}$.

Lamrini A, Bouymajjane A. 2002. Biologie de Dentex maroccanus (Valenciennes, 1830) dans la re'gion de Safi. Actes de l'Institut Agronomique et Ve'te'rinaire Hassan II, Rabat, 22, 11-18pp.

King M. 1995. Fisheries Biology, Assesment and Management, Fishing New Books, 352p.

Mohdeb R, Kara MH. 2014. Age, growth and reproduction of the Morocco dentex Dentex maroccanus of the eastern coast of Algeria, Journal of the Marine Biological Association of the United Kingdom,1-10 pp.

Morgan MJ, Hoenig JM. 1997. Estimating maturity-at-age from lenght stratified sampling. J. Northw. Atl. Fish. Sci., 21: 5164.

Murua H, Kraus G, Saborido RF, Witthames PR, Thorsen A, Junquera S. 2003. Procedures to estimate fecundity of marine fish species in relation to their reproductive strategy. JNAFS, 33: 33-54.

Murua H, Saborido-Rey F. 2003. Female Reproductive Strategies of Marine Fish Species of the North Atlantic. JNAFS, 33: 23-31.
Murua H, Ibaibarriaga L, Alvarez P, Santos M, Korta M, Santurtun M, Motos L. 2010. The daily egg production method: A valid tool for application to European hake in the Bay of Biscay, Fisheries Research, 104: 100-110.

Myers RA, Barrowman NJ. 1996. Is fish recruitment related to spawner abundance? Fish. Bull. 94: 707-724

Roof DA. 1981. Reproductive uncertainty and the evaluation of iteroparity: why don't flathfish put all their eggs in one basket? Can. J. Fish. Aquat. Sci., 38: 968-977.

Somarakis S, Palomera I, Garcia A, Quintanilla L, Koutsikopoulos C, Uriarte A, Motos L. 2004. Daily egg production of anchovy in European waters, Ices J of Mar. Sci., 61(6): 944-958.

Somarakis S, Ganias K, Siapatis A, Koutsikopoulos C, Machias A, Papaconstantinou C. 2006. Spawning habitat and daily egg production of sardine (Sardina pilchardus) in the eastern Mediterranean. Fisheries Oceanography, 15(4): 281292.

Stratoudakis Y, Bernal M, Ganias K, Uriarte A. 2006. The daily egg production method: recent advances, currentapplications and future challenges. Fish and Fisheries, 7: 35-37.

Taylan B, Hossucu B. 2016. Daily Egg Production Method for Spawning Biomass of European Anchovy Engraulis encrasicolus (Linnaeus, 1758) in Edremit Bay (Aegean Sea). FEB, 25: 4742-4746.

Trippel EA. 1998. Egg size and viability and seasonal offspring production of young Atlantic cod. Trans. Am. Fish. Soc., 127: 339-359.

Trippel EA. 2003. Estimation of Male Reproductive Success of Marine Fishes. JNAFS, 33: 81-113.

Valladolid M, Przybylski M. 2008. Life history traits of the endangered Iberian loach Cobitis calderoni in the River Lozoya, central Spain. Folia Zoologica, 57 (1-2): 147-154.

Whitehead PJP, Bauchot ML, Hureau JC, Nielsen J, Tortonese E. 1986. Fishes of the North-eastern Atlantic and the Mediterranean, Paris, Volume III, 1287-1289 pp. 